\author{
Ervin Csizmadia
}

\title{
DEMOCRACY AS A PROCESS - THE APPLICABILITY OF NORBERT ELIAS'S THEORY TO POLITICAL SCIENCE
}

Ervin Csizmadia, Senior Researcher, Centre for Social Sciences, Hungarian Academy of Sciences, Centre of Excellence, Institute for Political Science, csizmadia.ervin@tk.hu

This essay adapts Norbert Elias's transition theory - presented in The Civilizing Process - to Hungarian politics, specifically to the period between 1989-1990, following the change of regime. The first part of the essay summarises what figurational sociology meant for Norbert Elias and outlines how the analysis will be based on these two terms. The second part explores the limits of "condition" centred political science in the period following 1990 and comes to the conclusion that there is a strong relation between the mainstream teleological approach to democracy and "condition" centred political science. In the third part, the author introduces the concept of an open-ended transition as the key element of post-regime change figurational political science and outlines a figurational approach to political science. The essay ends with a short summary which states that, following the post-transitology era, new approaches need to be applied when describing Hungarian politics.

KEYWORDS:

teleology, condition centred political science, figurational political science, regime change, change 


\section{INTRODUCTION}

For a long time after the regime change, Hungarian democracy was a favourite with Western analysts and observers. Since 2010, however, the regime hallmarked by the name of Viktor Orbán has often been described not as a democracy but as a hybrid system, partly dictatorship and partly democracy. This raises the question of change in a democratic system. Is a democracy permitted to change, and if so, in what direction, and how? In principle, everyone agrees that it is, of course. However, those who use the term "hybrid system" clearly do not believe that the changes introduced under the Orbán regime fit into the 'range of change' within a democracy. ${ }^{1}$ Of course, supporters of the government side sharply disagree with this group of critics. They believe that the illiberal (or, more recently, Christian Democratic) system introduced by the government remains largely within the democratic framework, i.e. what happened between 2010 and 2021 is a 'natural' change or development of democracy. ${ }^{2}$

Political science has long been aware that democracy is a fragile system ${ }^{3}$ and is highly exposed to change. Yet research into the nature and dynamics of change is a relatively neglected area of the discipline. ${ }^{4}$ This is all the more true of democracies that did not evolve as a result of long historical development. The Hungarian democracy established in 19891990 is a good example of this, as the last thirty years have seen a number of unforeseen and unexpected changes. Moreover, the nature and drivers of these changes are not fully understood.

In this paper, I attempt to make a break from the usual explanations. I shall not be content to assert that democracy has become non-democracy. Instead, I shall try to provide a change theory explanation of the three decades of development of Hungarian democracy. This concept is not unknown in political science, and I have tried to apply it elsewhere - albeit focusing primarily on parties. ${ }^{5}$ The problem I want to address now does not really concern changes in democracy, but the question of whether changes can or should be interpreted as transitions between states or as phases of a process. Reviewing the political science of the more than thirty years between 1990 and 2021, one may be left with the impression that the discipline regards democracy as a state, or a layering of states, rather than a process. In the debate on state versus process (if there is a debate at all), I will

András Bozóki and Dániel Hegedűs, 'A kívülről korlátozott hibrid rendszer - Az Orbán-rezsim a rendszertipológia tükrében', Politikatudományi Szemle 26, no 2 (2017), 7-32. See also Balázs Böcskei and Andrea Szabó, Hibrid rezsimek - A politikatudomány X-aktái (Budapest: MTA Politikatudományi Intézet - Napvilág Kiadó, 2019). For more comprehensive information on hybrid systems, see Mariam Mufti, 'What do we know about hybrid regimes after two decades of scholarship?, Politics and Governance 6, no 2 (2018), 112-119.

Gallai (2020) argues in this direction.

William A Galston, 'The Enduring Vulnerability of Liberal Democracy', Journal of Democracy 31, no 3 (2020), $8-24$.

Gergely Rajnai, 'Miért sebezhetők a liberális demokráciák?’ Méltányosság Politikaelemző Központ, 2020.

Ervin Csizmadia, Politikai változáselmélet. Miért változnak pártok, kormányok, politikusok? (Budapest: L'Harmattan, 2007). 
draw on the work of Norbert Elias (2004). Although his book was written a long time ago and he did not deal with theoretical issues of democracy himself, his works offer ample references and explanations to help better understand the problem at hand. Elias argues against static sociology from a process sociology perspective. I intend to do the same in the field of political science.

The first part will briefly summarise what static versus process sociology meant to Norbert Elias, noting that I consider these categories to be useful for future reference. In the second part, I will sketch the outlines of the static interpretation of the post1990 period, concluding that static political theory stems from a teleological interpretation of democracy. In the third part, I introduce the concept of open-ended regime change as a key element of a process-oriented approach to the post-transition period, and attempt to develop a process-oriented approach. Finally, I will conclude with a brief summary.

\section{ELIAS AND THE THEORY OF PERMANENT CHANGES}

German sociologist Norbert Elias is not a contemporary thinker: he died, at ninetythree, in 1989 - the year of the regime change in Hungary. When seeking guidance on how democracies work today, this fact in itself would put Elias at a disadvantage. Besides, Hungary is by no means the subject of the work I will be referring to, although it might be included as such by extension. After all, the monumental tome entitled The Civilizing Process $^{6}$ is an attempt to interpret, in a way, the whole of human history. Finally, it should be noted that Elias was a sociologist, his theory was a sociological one, and the tenets he questioned were posed by other sociologists - hence, it may seem a bit far-fetched to focus on him in the context of contemporary political science.

What makes Elias relevant for this subject is precisely his viewpoint: it elaborates a process-centred approach. While his book first appeared in 1936, it should be borne in mind that the second edition saw the light of day in the summer of 1968. For the new edition, Elias wrote a fifty-page introduction to summarise his views on the development and the dynamics of social processes. I will quote only a few excerpts that are pertinent to prove how relevant his message is when examining the last thirty years of Hungarian democracy.

The first thing to consider is duration. Elias focuses a process of civilisation that really cannot be seen as short-term. He is concerned with 'long-term transformations of social structures', and in this our aims converge. However, 'long-term' means one thing from a historical perspective, and another if the focus is on the period after 1990. At any rate, starting from the premise that it is possible to refer, for example, to the Horthy and

Norbert Elias, The Civilizing Process. Sociogenetic and Psychogenetic Investigations, $2^{\text {nd }}$ edition (Oxford: Basil Blackwell, 2000). 
Kádár regimes and, more recently, to the Orbán regime, then such periods can be seen as somewhat long-term.

In the study of long-term historical processes, Elias notes that, 'we take leave of the metaphysical ideas which connect the concept of development either to the notion of mechanical necessity or to that of a teleological purpose'. This approach is indeed fully applicable to Hungarian democracy since 1990. As will become apparent, the problem with most contemporary mainstream theories consists precisely in the fact that they are much too teleological - they set out to 'follow' a certain state of democracy as it develops. As a result, they have difficulty digesting the fact that in the process of democracy, things do not always work out as planned or expected.

This issue was also the culmination of Elias's debate with his peers. He criticised other prominent scholars of his time, above all Talcott Parsons, whose name is better known in Hungary and who is regarded as the founder of systems theory. Elias thought (whether rightly or wrongly is not the issue here) that Parsons's approach was a static approach to sociology, i.e. one describing states without grasping the factors that lead to change. For our present purposes, it is enough to state that Elias distinguished between static sociology and process sociology.

Static sociology implies 'the hypothesis that every society normally exists in a state of [...] equilibrium'. ${ }^{8}$ This state of rest is only occasionally shaken by various events, which are derivatives of the state of rest, accidental and transient. Elias's main criticism of static sociology is that '[i]n this way the problems of social change are in a sense frozen and rendered innocuous to statically-orientated sociology'.

Elias also criticises Parsons's model of society as a 'social system', which is also 'at rest' it only changes under the influence of other systems. Elias disagrees with the position of traditional sociology which equates society with the social system, nor does he agree with its claim that the 'normal' form of existence of the social system is a state of rest. In Elias's view, this is not true because changes do not affect people from the outside, but from within: the nature of human relationships undergoes transformations, and this, in turn, brings about change.

This brings us to possibly Elias's most relevant idea for the present study: his theory is meant to be about human beings. The reason why he does not consider Parsons's idea to be human-centred enough is precisely that it is equilibrium-centred and static. In Elias's view, there is no need to abstract from the process character of both the 'individual' and 'society'. 'Indeed', he writes, 'it is indispensable that the concept of process be included in [...] theories relating to human beings'. ${ }^{10}$

It is worth recalling, of course, that Elias examines process character and humancentricity in terms of civilisation (more specifically, the emergence and development

Elias, The Civilizing Process, 451.

Ibid. 456.

Ibid. 457.

Ibid. 455 . 
of feudalism). This is clearly very far from the problems of Hungary in recent decades. In a conceptual sense, however, there is an overlap between studying the process of civilisation and examining the process of the period after the Hungarian regime change. Drawing on these ideas of Elias, two questions will serve as the starting point for this paper: 1 . how can the post-regime change era be construed, not as a teleological narrative (realisation of a pre-existing pattern) but as an open-ended process; and 2. how can this era be interpreted in a process-centred manner?

\section{TELEOLOGICAL PURPOSE: A STATIC POLITICAL THEORY NARRATIVE OF THE POST-REGIME CHANGE ERA}

For political science, it is evident that things keep changing. But how do we interpret the notion of change? The task is relatively simple in the case of old and well-functioning democracies, where change is part of their normal operation, and minor or even major setbacks are seen as the natural concomitants of democracy. It is a peculiarity of new democracies, in contrast, that internal change cannot (at least initially) be viewed as part of their normal operation; changes are regarded as more of a risk than a natural selfdevelopment.

Indeed, in political science, a new field of study called transitology ${ }^{11}$ emerged with the intention of interpreting the democratic transition and subsequent changes in East Central Europe. Transitology was invented to explain what was going on in transition countries. Admittedly, it did in many ways live up to that promise. In 2002, however, the end of transitology was announced by a renowned political scientist. ${ }^{12}$ It came to an end because, although it was sensitive to change in a sense, it was insensitive in substance, unable to properly interpret the dynamics of the post-transition situation. As Elias might have put it, it remained static; it failed to become process-centred. It is still worth considering, however, what transitology's specific interpretation of change meant.

The starting point for this paradigm as a whole is the claim that democratisation itself follows a universal pattern: the victory of democracy in East Central Europe is the final victory of democracy on a historical scale. As this victory becomes irreversible in East Central Europe (since with the collapse of the Soviet Union, there are no longer any systemic opponents), the new democracies in the region must follow the path of democracy building as quickly as possible. Thus, transitology was, to its credit, more than merely a study of transition. It did not stop at indicating what a direct transition from dictatorship

11 Wikipedia has a separate page devoted to the conceptual presentation of transitology, and mentions its major authors.

12 See Thomas Carothers, 'The End of the Transition Paradigm', Journal of Democracy 13, no 1 (2002), 5-21. On transitology and the lessons it offered, see Ervin Csizmadia, A tranzitológiának vége, felejtsük el? - Az átmenet tervezett intézményeitől a tervezetlen hibridizációig', Politikatudományi Szemle 25, no 2 (2016), 135-153. 
to democracy should be like, but went on to trace the phases that must be followed within democracy for the global victory of democracy to be completed.

All of this required a tremendous transformation of Western political science, one that took place between 1970 and 1990. In 1970, Dankwart Rustow wrote one of the first theories of transition. While his work described transitions that took place in the early $20^{\text {th }}$ century, it did not lend itself to be applied to subsequent developments in East Central Europe. Rustow's model comprised a three-stage transition made up of a pre-transition crisis, a democratic transition, and the consolidation of democracy. Rustow himself describes the model as dynamic, that is to say, the transition does not end with one state being replaced by another, but is in fact a state of continuous change. Rustow's work was rediscovered during the period of regime change in East Central Europe; it was a common perception at the time that regime change might last for a lengthy period. In the spirit of this 'long regime change', the slogan was that it was easy to change a system, but it was much more difficult to change the economy, and it was even more difficult to change and democratise civic behaviour. To put it another way, some authors distinguished between early and mature democracy, identifying the latter with the expansion of democratic attitudes. ${ }^{13}$ In other words, they saw a development taking place between opposing camps. There are exemplary democracies on the one hand, and new democracies trying to catch up and adapt on the other. The aim of the latter, in this scheme, is simply to follow the path that the theorists of transitions have laid out for them, as quickly as possible. This can be considered a teleological plan or (in the words of Elias) a 'teleological purpose', albeit with the demonstration of some kind of democratic development dynamics.

Subsequent developments largely justified this notion of the progress to democracy, a teleological and somewhat mechanical process: by the mid-1990s, Hungarian democracy had passed the early democratic phase and begun to consolidate. In the second half of the decade, many domestic and foreign observers alike believed that Hungary had come close to a state of mature democracy. During this period, little attention was paid to an essay written by Fareed Zakaria (1997), in which he described the strengthening of illiberal systems - albeit not in relation to East Central Europe.

The picture painted by transitology, then, focused on the progress of democracy. From this perspective, it seemed clear that democracy could only move towards its fulfilment, and that any error in the mechanism could only be caused by politicians and/or parties 'misinterpreting' the democratic agenda. The problem with this approach was not that it failed to register changes, but that it interpreted them narrowly and teleologically. Consequently, it failed to do justice to the dynamics that Rustow had considered so important, or interpreted them only in terms of democracy taking shape in a predetermined manner.

13 From the extensive literature, see Attila Ágh, 'A korai konszolidáció és az EU-alkalmazkodás Közép-Európában', Politikatudományi Szemle 10, no 1-2 (2001), 25-44. 
That being so, transitology was capable of no more than capturing a static image of Hungarian democracy. It could have done better, however, had it been more faithful to its own propositions. After all, one reason why transitology became popular in the late 1980s was that it did not only supply a blueprint for democracy building but also helped reinterpret the role of political actors. Until the late 1980s, Western political scientists had not thought it feasible to take action against dictatorships; from then on, however, it was found that action did indeed make sense. It was precisely the actors taking the stage during this period that created the conditions and specific characteristics for a democratic transition following the transitological blueprint. It was this circle that - partly within the ramparts of power, partly on its outskirts, and beyond - became the custodians of Western thinking and whose articles on the subject were printed in journals and newspapers. And yet, no matter how thoroughly transitology had charted out the nature and sequence of the stages of democratisation, it had little to say about the intergenerational succession of political actors or the conflicts between consecutive generations, now within a democratic framework. The teleological vision of democracy building offered an 'indivisible' image of the actors, and it did not anticipate that political actors ready to reach consensus at the time of the regime change would later come into conflict with one another, or that some of them would end up stretching the boundaries of established forms of democracy.

Of course, in the mid-1990s, transitology also started to deal, among other things, with the increasingly active Fidesz generation, but an in-depth analysis of the changes the party went through remains unwritten to this day. As a rule, mainstream literature has sought to describe the metamorphosis of Fidesz as a phenomenon in its own right, and not as the result of interaction with other factors. Related to this viewpoint is the one-sidedness that is a recurring feature of interpretations of the Fidesz story. The mere observation that Fidesz ended up a populist party fails to explain why, if at all, it did so, and what factors external to Fidesz played a role in this. Hence, a great number of papers on the topic neglects the analysis of the mutual and contextual relations between parties and other political actors, or between parties and events. In fact, politics is a team game in which the actions of each actor are determined by many factors, but mostly by the movements of rival actors. Hence, the issue of interactions is very closely linked to that of changes, and I would suggest that this can be proved not only by looking at the current political scene but can also be applied to the broader processes of the development of political parties in Hungary.

To summarise: transitology was fraught with two problems. On the one hand, it was teleological and could only describe changes as components of a democratic plan, while on the other hand, it was incapable of doing justice to the generational perspective in interpreting the movements of political actors, nor did it take sufficient account of the fact that, in addition to the protagonists of transition, other actors might also take the stage and pursue their own agendas. As a result, transitology recorded a sequence of states and not a dynamic process. Admittedly, the dynamics of a process are not easy to trace. To accomplish this, it is necessary to set aside the teleological approach and interpret 
democracy not as the implementation of a predetermined democratic plan, but as an openended game.

\section{A PROCESS-ORIENTED APPROACH TO OPEN-ENDED TRANSITION AND THE POST-REGIME CHANGE ERA}

Transitology was the prevailing theoretical approach during the process of democratisation. In contrast, with thirty years of experience, and with the benefit of hindsight, the weak points of the early theory can be better discerned. I described these above. The task now is to create a better theoretical framework, and in order to do so at all, we must first give up the teleological nature of transitology. As I pointed out, Zakaria noticed as early as 1997 that a group of illiberal systems was emerging which cast doubt on the theory of the global victory of liberal democracy, that is, it had already become clear even by that stage that the original theory was not working. Taking a cue from Zakaria, a huge body of literature began to deal with what was actually happening and why the early optimistic agenda had failed to materialise. ${ }^{14}$

Clearly, it is best to assert at the outset that the process starting with a regime change has no teleological purpose. Describing civilisation, Elias says that in the human world, there are many figurations that no human being intended, and yet they arise. He argues that the organisation of the human will is the key. The change of regime in Hungary, however, seems to have been of a different character, as the elites here really wanted something - they wanted to create democracy. Elias even says that civilisation is not rational - nor is it irrational - but 'is set in motion blindly, and kept in motion by the autonomous dynamics of a web of relationships.'.

While it would be an exaggeration to talk about 'blind progress' in connection with the Hungarian transition, it is certainly worth considering the concept of open-ended regime change. ${ }^{16}$ Such a viewpoint opens up a completely different perspective than the 'closed-ended' theory (which interprets changes as events taking place within a specific form of democracy).

To switch from the transitologist approach to the perspective of an open-ended regime change, two conceptual adjustments are needed. The first is to replace the idea of a 'planned

\footnotetext{
Basically, this literature is grouped around three concepts (populism, illiberalism, hybrid system).

Elias, The Civilizing Process, 367, 467.

I write about this in detail in another study: Ervin Csizmadia, 'Ellenzékiség, aktorok és a demokrácia nyitott kimenetele - Az 1990 utáni Magyarország példája’, Politikatudományi Szemle 28, no 4 (2019), 89-116. Körösényi and Gyulai argue in a similar way against teleological approaches (András Körösényi and Attila Gyulai, 'A hibridrezsim-fogalom korlátai és egy alternatív megközelítés: a plebiszciter vezérdemokrácia', in Hibrid rezsimek - A politikatudomány X-aktái, ed. by Balázs Böcskei and Andrea Szabó (Budapest: Politikatudományi Intézet - Napvilág Kiadó, 2019), 159-178.
} 
transition'17 with a transition wrought with a great deal of uncertainty and plenty of unpredictable elements. This does not, of course, amount to saying that the Hungarian transition had no conscious constituents. Yet the best-laid plans of mice and men often go awry - reality tends to take directions that no one ever anticipated. The other adjustment is warranted by the dynamically changing dominance relations within the political elite, which again can reshape the conditions prevailing at the beginning of the process. Thus, it is necessary to take a closer look at these two factors, by first examining the notion of 'open outcome' and the reasons why the planned image of democracy is not being realised, and then identifying the changes in dominance relations.

The static approach rests on the hypothesis that the idea of democratisation was, by the end of the 1980s, ready and waiting to be transposed and implemented. The theory of an open outcome of democracy is a dynamic approach, precisely because it assumes that this was by no means a given, and that there was less consensus about the implementation of democracy than was previously assumed. In order to understand what is at stake here, it is necessary to dispense with the view that only one scenario prevailed during the transition, and that it made steady, inevitable progress.

The Western expectation can be described as follows: 1 . The paradigm of transition arises. 2. In the target countries, an elite capable of leading the transition gets organised. 3 . The old system is swept away by combined Western and domestic influences. 4 . In the new system, Western-type democracy building begins, which progresses continuously through various phases.

John Gray (1993), however, points out that there are non-mainstream trends in political science with completely different roadmaps for democracy, and that there are more ways for countries seeking to catch up than the one expected by the mainstream. This 'unexpected' mode introduces an important new element: the nation's own history, which Gray describes as pre-Soviet particularism. 'Openness' is thus already registered at the early stage of democracy, which implies a reading of regime change different from the 'closed' theory of democratisation. Accepting that the historical past of a country plays a role in democratisation right from the outset brings a different kind of dynamics to its processes than the approach where democratisation means the transposition of Western patterns. Although transitology did not recognise the existence of simultaneous rival theories, they did in fact exist. Without a doubt, the rival theories were far from less prominent than they later became. Until the mid-2000s, these theories, rooted in national history, did not even seem to be important components of the transformation of the competition between parties.

From this realisation, a more dynamic interpretation readily arises. It becomes clear that (at least) two readings of the Hungarian regime change have coexisted from the beginning: one called for the transposition of Western patterns, while the other expected

17 The best explanation of the term can be found in Claus Offe, 'A kelet-európai átmenetek intézményeinek tervezése', Politikatudományi Szemle 3, no 3 (1994), 5-32. 
the reconstruction of Hungarian political and historical traditions. The impression that all the relevant actors after 1990 were proponents of adopting Western examples eventually turned out mistaken. Of course, no one wanted an Eastern type of democracy, but there were already differences of opinion regarding the extent to which the traditions of pre1945 Hungarian political history would come to life in the new democracy.

Another dynamic factor was also present: the rearrangement or concentration of the party system. The best analysis of this is that of Csaba Tóth (2001). He rightly observed that domestic analysts were judging the role of the parties statically, so he focused his interest instead on the process of concentration. His investigation was discontinued, even though the really interesting dynamic changes occurred after 2001 when the Western and 'differently Western' camps clearly and perhaps conclusively separated. Yet it bears repeating that this change cannot be deduced from the transitological paradigm, whose representatives never imagined such a change taking place during the development of democracy.

Of course, just as on the eve of the regime change and afterwards, the dynamics hinged on the elites. Yet the limitation of a static approach is that it pays little attention to the dominance relations between elites. This is all the more crucial, since in terms of dominance, the last thirty years have seen very important changes indeed.

To begin with, the prevailing notion of the West was linked to a specific intellectual elite from an early stage of the transition. In essence, they reinterpreted a well-known attitude of Hungarian political history: you take your cue from the West. This was of great utility during the years of transition. However, the emergence of this intellectual elite did not put an end to the 'process of selection' of the relevant actors. Other groups also existed that, at the time, were not willing or able to get involved, or, if they were prepared to do so, their role was marginal in the early days. The early stage can also be understood in the sense that the Westernness of the regime change was represented by a certain political generation, the one that considered action to be meaningful; in this case, action meant the dismantling of the dictatorship and the creation of democracy. In a teleological view, this generation (or perhaps other generations sharing the same view) should have succeeded in implementing democracy. The point is that political action has a canonised direction, and deviation from it is seen as deviance. However, if it is true that (as was mentioned above in connection with John Gray), at the time of the transition, another - however embryonic - paradigm of thinking emerged along with the mainstream one, then this suggests that the historycentric conception of newer generations produced its own advocates, and the newly organised elites sought a new approach, which presents us with a different picture than that projected by the mainstream perception. This different perspective is one in which nothing is pre-ordained, where the path to democracy is not pre-set.

The relationship between the static and dynamic approaches is best illustrated in this generational cross-section. First of all, there was the generation of the regime change that took on the historic task of creating democracy in Hungary. Understandably, this generation built on the international trend of a global victory for democracy, and concludes from this that once democracy is introduced, what remains is only an 'expansion' of democracy 
or, as many expressed it at the time, the implementation of mature democracy after early democracy. ${ }^{18}$ What is static about such a model? The claim that development is purposeful and one-way; that it can be no other way. The younger generation in politics refuted this picture of development through its own generational organisation: the Fidesz generation was interpreting democracy differently than the older generation from as early as the mid1990s.

This can be illustrated by taking the example of consensual democracy. The prevailing attitude of the regime change envisaged that a consensual democracy should be established in Hungary - after a short transition. Why? Because this was regarded as almost a requirement for a transition. Alternatives to the interpretation of consensual democracy are well illustrated by one of András Körösényi’s (1993) early writings, but it only became clear later that the younger generation were, to put it simply, no believers in consensual democracy. ${ }^{19}$ It is now irrelevant which party was, or is, right on this issue. What is important is only to state that the interpretation of democracy is definitely a dynamic factor and overrides the static attitude which assumes the consolidation of early democracy. Since the Fidesz generation finally matured in a political sense, the conception of democracy it represents entered the bloodstream of public life, and since then it has been the crucial factor in motivating political competition.

The mere affirmation that Fidesz eventually became a populist party misses the point. To wit, the point can be grasped in two dimensions. The first is the dimension of present versus history. According to the static approach, the present has priority over history. The second dimension is consensual versus majority democracy. The static position here is that only the first interpretation of democracy is acceptable.

In both dimensions, I argue that the dynamic approach is most appropriate. Namely, as 1. Hungarian political history has been playing an important role in the (trans)formation of political processes since the beginning of the transition; and 2. since the emerging form of democracy could not initially be classified as one or another 'pure' democratic model, a struggle started to ensure that the 'mixed' model would prevail. ${ }^{20}$ The left and liberal sides continue to prefer the consensual model, while Fidesz has preferred the majority model since the mid-1990s. Viewing things in terms of populism, reveals nothing of this, nor is it obvious that there were a number of moot issues in the party competition which needed to be resolved or, at least, raised.

On this basis, it can be concluded that dynamics is a key concept to use when interpreting the last thirty years of Hungarian democracy. It is only possible to attempt to

\footnotetext{
Ágh, 'A korai konszolidáció'.

19 To the best of my knowledge, Körösényi was the first author who did not interpret the situation after the change of regime according to the consensus principle that was customary at the time.

20 This is best described by Andrew Roberts (2006). He points out that, in contrast to Western democracies (where 'pure' models of democracy prevail), rivalry has existed between various conceptions of democracy in the East Central European region right from the outset. Moreover, the new institutions created are not uniform either, as both majority and consensual institutions can be found among them.
} 
answer the question posed at the beginning of the introduction (how it happened) if it is approached not in a closed but in an open manner.

\section{CONCLUSION}

This paper was written to express my respect and appreciation for Norbert Elias's comprehensive theory. I found that the two categories he applied to social science (static vs. process sociology) can also be applied to political science. Of course, it was not my intention to deal with Elias's theory of civilisation or debate the way he portrayed the development of Europe as a process. This would have stretched to the utmost the framework of a paper whose focus is on analysing the history of the Hungarian regime change.

However, an Eliasian line of reasoning may help reflect on our framework for interpreting politics. This framework, as applied to the regime change, was dictated by transitology, a worldview whose consequences are still being felt, even though transitology has passed. Transitology and its successor theories drew a straight-line, relapse-free, rather static picture of democracy, which led to the commonplace statement that the ideal state of democracy in Hungary was abolished by Fidesz. However, in such a summary format, this approach does not hold water. I am convinced that the last thirty years have been full of challenges, and that changes have taken place in a process, through the interaction of the movements of actors. Fidesz is only one player in this process, albeit the one actor who managed to decide the debate, present from the beginning of the period, on consensual and majority democracy to its own benefit (favouring the principle of majority).

Taking the hybrid system or populism as an interpretive framework is a futile effort to detect the key points in the process. From such a perspective, the importance of interaction between actors will be missed and populism will be erroneously described as a deformation in itself. Conversely, the process approach allows this misinterpretation to be corrected, and may help us arrive at a deeper understanding of, and a better explanation for, the developments in post-regime change Hungary. 


\section{REFERENCES}

1. Ágh, Attila, 'A korai konszolidáció és az EU-alkalmazkodás Közép-Európában'. Politikatudományi Szemle 10, no 1-2 (2001), 25-44.

2. Bozóki, András and Dániel Hegedűs, 'A kívülről korlátozott hibrid rendszer-Az Orbánrezsim a rendszertipológia tükrében'. Politikatudományi Szemle 26, no 2 (2017), 7-32.

3. Böcskei, Balázs and Andrea Szabó (eds), Hibrid rezsimek - A politikatudomány X-aktái. Budapest: MTA Politikatudományi Intézet - Napvilág Kiadó, 2019.

4. Carothers, Thomas, 'The End of the Transition Paradigm'. Journal of Democracy 13, no 1 (2002), 5-21. Online: https://doi.org/10.1353/jod.2002.0003

5. Csizmadia, Ervin Politikai változáselmélet. Miért változnak pártok, kormányok, politikusok? Budapest: L'Harmattan, 2007.

6. Csizmadia, Ervin, 'A tranzitológiának vége, felejtsük el? - Az átmenet tervezett intézményeitől a tervezetlen hibridizációig'. Politikatudományi Szemle 25, no 2 (2016), 135-153.

7. Csizmadia, Ervin, 'Ellenzékiség, aktorok és a demokrácia nyitott kimenetele Az 1990 utáni Magyarország példája’. Politikatudományi Szemle 28, no 4 (2019), 89-116. Online: https://doi.org/10.30718/POLTUD.HU.2019.4.89

8. Elias, Norbert, The Civilizing Process. Sociogenetic and Psychogenetic Investigations, $2^{\text {nd }}$ edition. Oxford: Basil Blackwell, 2000.

9. Gallai, Sándor, 'A demokrácia kisajátítása'. Corvinák, 03 December 2020. Online: https://corvinak.hu/velemeny/2020/12/03/a-demokracia-kisajatitasa

10. Galston, William A, 'The Enduring Vulnerability of Liberal Democracy'. Journal of Democracy 31, no 3 (2020), 8-24. Online: https://doi.org/10.1353/jod.2020.0042

11. Gray, John, 'From Post-Communism to Civil Society: The Reemergence of History and the Decline of the Western Model'. Social Philosophy and Policy 10, no 2 (1993), 26-50. Online: https://doi.org/10.1017/S026505250000412X

12. Körösényi, András, 'Kié a hatalom? A hatalom pluralitása Magyarországon, 19901992'. Politikatudományi Szemle 2, no 4 (1993), 5-20.

13. Körösényi, András and Attila Gyulai, 'A hibridrezsim-fogalom korlátai és egy alternatív megközelítés: a plebiszciter vezérdemokrácia', in Hibrid rezsimek - A politikatudomány X-aktái, ed. by Balázs Böcskei and Andrea Szabó. Budapest: Politikatudományi Intézet - Napvilág Kiadó, 2019, 159-178.

14. Mufti, Mariam, 'What do we know about hybrid regimes after two decades of scholarship?' Politics and Governance 6, no 2 (2018), 112-119. Online: https://doi. org/10.17645/pag.v6i2.1400

15. Offe, Claus, 'A kelet-európai átmenetek intézményeinek tervezése'. Politikatudományi Szemle 3, no 3 (1994), 5-32.

16. Rajnai, Gergely, 'Miért sebezhetők a liberális demokráciák?' Méltányosság Politikaelemzö Központ, 2020. Online: https://meltanyossag.hu/wp-content/uploads/2020/12/ miert-sebezhetok-a-liberalis-demokraciak.pdf 
17. Roberts, Andrew, 'What kind of democracy is emerging in Eastern Europe?' PostSoviet Affairs 22, no 1 (2006), 37-64. Online: https://doi.org/10.2747/1060-586X.22.1.37

18. Rustow, Dankwart A, 'Transitions to Democracy: Toward a Dynamic Model'. Comparative Politics 2, no 3 (1970), 337-363. Online: https://doi.org/10.2307/421307

19. Tóth, Csaba, 'A magyar pártrendszer fejlődésének fő iránya'. Politikatudományi Szemle 10 , no 3 (2001), 81-104.

20. Zakaria, Fareed, 'The Rise of Illiberal Democracy'. Foreign Affairs 76, no 6 (1997), 2243. Online: https://doi.org/10.2307/20048274

Ervin Csizmadia is a Senior Researcher at the Centre for Social Sciences, Hungarian Academy of Sciences, Centre of Excellence, Institute for Political Science. He deals with parties, political conflict, think tank organisations, power and opposition, and American and Hungarian political development. 